\title{
Cautious welcome for new head of Euro-patent office
}

Munich. After almost a year of political wrangling, the council of the European Patent Office (EPO) last week elected Ingo Kober, state secretary of the German Ministry of Justice, as its next president. But the choice of a German has sparked concern among the EPO's 3,700 staff, half of whom are based at the Munich headquarters, next door to the German patent office, one of the strongest national patent offices in Europe.

The two offices have frequently been in dispute over the better conditions of employment at the European office, as well as the possible decentralization of tasks, such as patent searches, from the EPO to national offices. The EPO staff union, which represents at least threequarters of employees, has long argued that the election of a German president could increase internal conflict (see Nature 371, 371; 1994).

But such concern may be misplaced. Kober's election was unanimous, and he is a

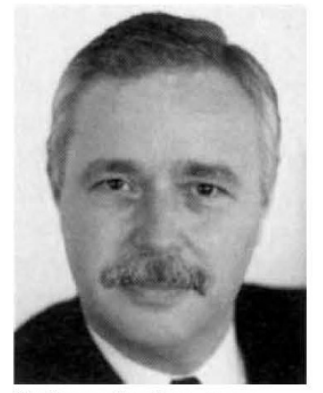

Kober: denies any conflict in loyalties. popular choice outside the EPO. EPO's 17 member states have had difficulty in replacing the current president, Paul Braendli whose second consecutive five-year term expires in April - and have voted inconclusively on the issue several times over the past nine months.

One reason the vote was split was that Braendli, who is Swiss, had put himself forward for a further three-year period. To leave more time for negotiation, Braendli's term was extended in September by eight months to the end of 1995. Member states also had to acknowledge a higher political agenda and consider the geographical shareout of other key European positions. Germany, for example, recently lost its postion as head of the North Atlantic Treaty Organization (NATO).

Many had expected the bargaining to extend well into next year. But after Switzerland withdrew Braendli's candidacy, Kober, who is 52, was last week voted in and will start his five-year term in January 1996.

Kober, who is a lawyer with a strong background in patent affairs, headed the German delegation to EPO from 1987 to 1991. Since 1991 he has been state secretary of the justice ministry, where he has worked for nearly 20 years, with particular interest in the legal aspects of patent protection.

His reputation as hardworking and competent, with a good ability to get along well with people, will be crucial in addressing the concern of the EPO staff, who are frequently criticized in the German press for enjoying high salaries and special privileges, such as exemption from income tax.

These criticisms have been led by the Bavarian branch of the Free Democrat party (FDP), the small but influential political party supported mainly by small businesses and the self-employed, whose popularity fell in the October elections.

The president of the German Patent Office, Erich Häusser, is also an FDP member, and is known to be unhappy that employees in his organization are paid less than their EPO neighbours for doing similar work. The fact that Kober himself is an FDP member is not reassuring to EPO staff, who feel that Germany has never publicly defended their interests.

"We now want the German delegation [to the $\mathrm{EPO}$ ] to stand up for us in public, and point out the economic benefits for Germany in having the EPO here," says Anders Sunnhagen, chairman of the union. If it does not, he says, staff will ask the next council meeting in June to debate a motion that Germany is not taking seriously its responsibilities as host country, and that all or part of the EPO should be moved elsewhere.

Kober says he will discuss the matter with the unions to try to defuse the situation. $\mathrm{He}$ claims that he fully understands the unions' view that their conditions of employment should be compared to other international organizations and not to the German patent office.

Kober says that as president of the EPO, his loyalty to the office will not be affected by national concerns. His main aim, is to improve the efficiency of the office, and to reduce the time involved in issuing patents.

He expects to continue the major changes introduced by Braendli, such as automating the office at a reasonable price - a sometimes controversial issue because of the high costs involved - and studying ways to reduce or restructure EPO's high fees, which small businesses and academics often cannot afford.

On the issue of decentralization, Kober believes that there is room for the limited devolution of tasks to national offices under existing EPO rules, but says he has no specific plans in mind.

Von Benthem confirms Kober's European credentials: "When he was a member of the German delegation to the EPO, he often went against the interests of the German patent office in favour of the EPO," he says. There is no reason to suspect that this will change when Kober becomes president, he adds.

\section{Promega files court challenge to Roche's Taq enzyme patent}

London. Promega, the US laboratory supply company, has stepped up its fight against the patent owned by the Swiss pharmaceutical company Hoffman-La Roche on the thermostable enzyme Taq DNA polymerase by challenging the validity of the US patent in an action filed last week in a San Francisco court.

Promega claims that Taq polymerase, which is used in almost all molecular biology laboratories, was known to scientists before its 'discovery' by scientists at Cetus Corporation in 1985. In support of its case, the company cites in particular a thesis, written by a research student at the University of Cincinnati in 1974, describing the properties of a polymerase which it claims to be identical to that later purified by Cetus.

As other examples of 'prior art', Promega refers to work published in the Journal of Bacteriology in 1976 by a group of Cincinnati scientists, as well as the results of research by a group of Russian scientists published in the Soviet Union in 1980.

Similar arguments have already been rejected by both the US Patent Office and the European Patent Office (EPO) in Munich. EPO recently told Hoffmann-La Roche - which purchased the rights to both Taq and its most common application, the polymerase chain reaction (PCR) process, from Cetus for $\$ 300$ million in 1991 - that it intends to issue the company with a broad European patent covering thermostable polymerases (see Nature 372, 212; 1994).

Roche is also suing Promega for breaking a licensing agreement signed with Cetus. An attempt by Promega to head off this suit by challenging the validity of the patent has already been rejected by the courts. Many are interpreting the latest challenge as a new attempt by Promega to avoid paying the heavy costs of a licence violation.

But William Linton, president and chief executive officer of Promega, insists that a point of principle is at stake. "We believe that scientists [in the United States] should not be forced to pay a premium simply because a patent was granted based on erroneous and misleading information," he said last week.

According to Linton, "representations to the patent office of differences between the patented and the prior art polymerases made during prosecution of the [US] patent application are false".

But Agnieszka Junosza-Jankowski, licensing manager of Roche Diagnostic Systems, says the company considers Promega's arguments, which have already been addressed by patent officials, are "without merit". She adds: "We are confident that our position will prevail in court." David Dickson 